\title{
NARRATIVES, SPACE AND DRAMA: ESSENTIAL SPATIAL ASPECTS INVOLVED IN THE PERFORMANCE AND RECEPTION OF ORAL NARRATIVE*
}

\author{
Terry Gunnell
}

\begin{abstract}
In the past, oral narrative tended to be regarded as a two-dimensional phenomenon largely confined to the form of the spoken or (later) printed word. Over the last twenty years, however, oral narratives have gradually gained "thickness" in the eyes of folklore scholars who have increasingly demanded that more attention be paid to the social and personal contexts that gave rise to these narratives. This present article reviews the ways in which the understanding of oral narrative depends on its physical, mental and social surroundings, noting also how the process is actually reciprocal, since while taking much from their surroundings, narratives are also capable of subtly changing the contexts that gave birth to them. Working out from the three-dimensional nature of the oral narrative performance, it is argued that much could be gained from analysing oral narratives as pieces of theatre or dramatic performances rather than as pieces of text.
\end{abstract}

Key words: Folk narrative; drama; performance; space; storytellers

It might be argued that all folklore unconsciously involves ideas of boundaries and inhabited space, especially with regard to its relationship with the recurring concept of "us" and "them", and following on from this, the closely associated ideas concerning "otherness" and the "inside" and the "outside" of the worlds we inhabit. These ideas are probably most clearly reflected in the fields of festival, game and folk narrative: indeed, in the field of folk narrative studies, the concept of "space" has taken on ever-increasing importance over the last few years, especially with regard to the examination of the direct living context of the performance "event" that produced the story (see Bauman 1977:27-29), and then the role played by the space which the individual storyteller inhabited throughout his or her life. ${ }^{1}$

The central themes of the International Society for Folk Narrative Research Congress in Tartu, in 2005, were "Narrative Theories and Modern Practices". Without doubt, one of the key developments in the scholarly approach to the folk narrative over the last 150 years has been a gradual move away from the earlier approach of examining these narratives merely as a series of written or recorded words printed anonymously on a flat page below neat story headings. In such a form, oral narratives are as isolated from their context as dead butterflies pinned to a table for examination. Thanks to the work of Parry and Lord and their follow- 
ers, and then that of other key figures like Malinowski, Durkheim, Delarghy, Hymes, Holbek, Bauman, Röhrich, Dégh, Glassie, Siikala and Honko (just to mention a few), ${ }^{2}$ most scholars nowadays look at folk narrative from a very different viewpoint. They see it essentially as a living social phenomenon, something which has a historical, social and anthropological as well as a folkloristic context; something which is both uttered and - equally important - received, passed on, recreated and developed, not just as words but as a series of images, symbols, sounds, associations and textures. In short, as Lauri Honko stressed (Honko 2000: 1143), the text has gained "thickness". However, this is not just in terms of Honko's "organic variation". Folk narratives have simply begun to be seen as involving a much greater degree of "space" than they did at the time of the Grimms.

In this article, I would like to touch on a number of the different spatial aspects that are involved with different types of folk narrative, and hopefully expand a little on the concept of "context" which in the work of Bauman and his students in the United States and elsewhere tends to be concentrated on social and sociolinguistic factors rather than physical performance (see for example Ben Amos 1975 and the various works by Bauman cited elsewhere in this article). It is important therefore to start by underlining the well-known facts that a "typical" folk narrative not only takes place in space but also creates it. Far from the twodimensional published text, a living folk-narrative is essentially three-, if not four-dimensional. Like a stage play in the theatre, it takes place within a living space unconsciously "marked out" by the performer and the (often actively participating) observers, ${ }^{3}$ often as part of a wider conversation. And as people like Huizinga (1949: 13) and Schechner (2002: 11-15) have noted, the moment the individual "performance" begins, this area becomes marked off in some way: there is suddenly a new "inside" and an "outside". "Outsiders" observing this are aware that the "insiders" are involved in a separate delineated activity. At the same time, the "insiders" awareness of the outside world diminishes in relation to the degree of the attention they are paying to the activity. In short, the area has taken on the nature of what Huizinga would refer to as a "play" space, parallel in nature to a museum, an active tennis match, a law court, or a church (Huizinga 1949). It is a space that outsiders walk around, and feel wary about entering; an area which has simultaneously been bestowed with an element of "sacredness" (see Eliade 1958: 388-408; and 1964: 18-19) that should not be disturbed. It has become charged in some way, and very often also involves a different time scale, different behaviour and speech registers, different values, and a different momentum.

The suggestion was made above that the dynamics of the performance can be compared to those of a stage play. To my mind, this is a very fruitful approach albeit one that has rarely been utilised to the degree that it could be (see nonetheless Sándor 1967). ${ }^{4}$ In a sense, all living folk narratives can be seen as dramatic performances. This does not mean that a play ${ }^{5}$ is literally being presented, although it is well known that many storytellers regularly do step over the line into role-play with their voices and gestures, thereby immediately creating new parallel worlds in front of the eyes and minds of their "audiences" (see for example Gunnell 1995: 24; Tillhagen 1946: 11-18; Hodne 1979: 117; Scheub 1990: 49 
and 97; Cosentino 1998: 178; Dégh 1969: 184; and Zimmermann 2001: 492-194). Like actors in role, these performers also take on a "double" nature: each storyteller is seen simultaneously by his audience as both the performer and the role, the presence of the other role bringing another parallel world into existence in front of the audience's eyes, just as occurs in the theatre. Narrative performances of this kind are in essence a form of "kitchen-" or "pub theatre". They are certainly viewed by those involved in theatre as one of the earliest, most essential forms of theatrical performance.

What I mean, however, by the suggestion that all folk narratives (whether or not they involve role play) should be seen as a form of "dramatic" performance is that they centre around the dynamic of the central active performer and less active observers, and also - essentially - involve not only the ears but the eyes. In short, they actively involve various elements of visual context and visual semiotics (see Dégh 1969: 184; and Baumann 1977: 4). However, it is not only the visual presence of the performer that matters here but also the space around him or her which will unconsciously work like the "charged" scenery which provided the functional backdrop to the words and action of a stage play. Hamlet performed by a fat seventy-year old white man in a market in Africa will to be very different to Hamlet as performed by a young black female stand-up comic in front of the US Senate building. The same applies to any storytelling session. In short, as Bauman, Foley and others have stressed both the identity of the performer and the immediate context of the particular performance space matters greatly for the performance of an oral narrative. It might even be argued that when it comes down to it, the actual words of the performance (those words collected and written down in the folktale collections) probably make up less than half of the actual received semiotic "text" of the event which is, of course, also packed with other forms of message for its audience.

As John Miles Foley recently has underlined with regard to the understanding of oral poetry:

Any oral poem, like any utterance, is profoundly contingent on its context. To assume that it is detachable - that we can comfortably speak of "an oral poem" as a freestanding item - is necessarily to take it out of context. And what is the lost context? It is the performance, the audience, the poet, the music, the specialized way of speaking, the gestures, the costuming, the visual aids, the occasion, the ritual, and myriad other aspects of the given poem's reality... And when we pry an oral poem out of one language and insert it into another, things will inevitably change. We'll pay a price. (Foley 2002: $60)$.

Bearing this is in mind, it is worth considering the table assembled in 1988 by the German theatre scholar Manfred Pfister depicting the wide range of contextual messages that are simultaneously received during the course of a dramatic performance (see Fig. 1). Among other things, Pfister stresses not only the effects of both visual and auditory signals, but also a number of other factors such as the elements of touch and smell and prior expectations. All of these factors naturally 
Terry Gunnell

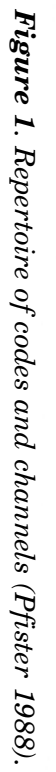
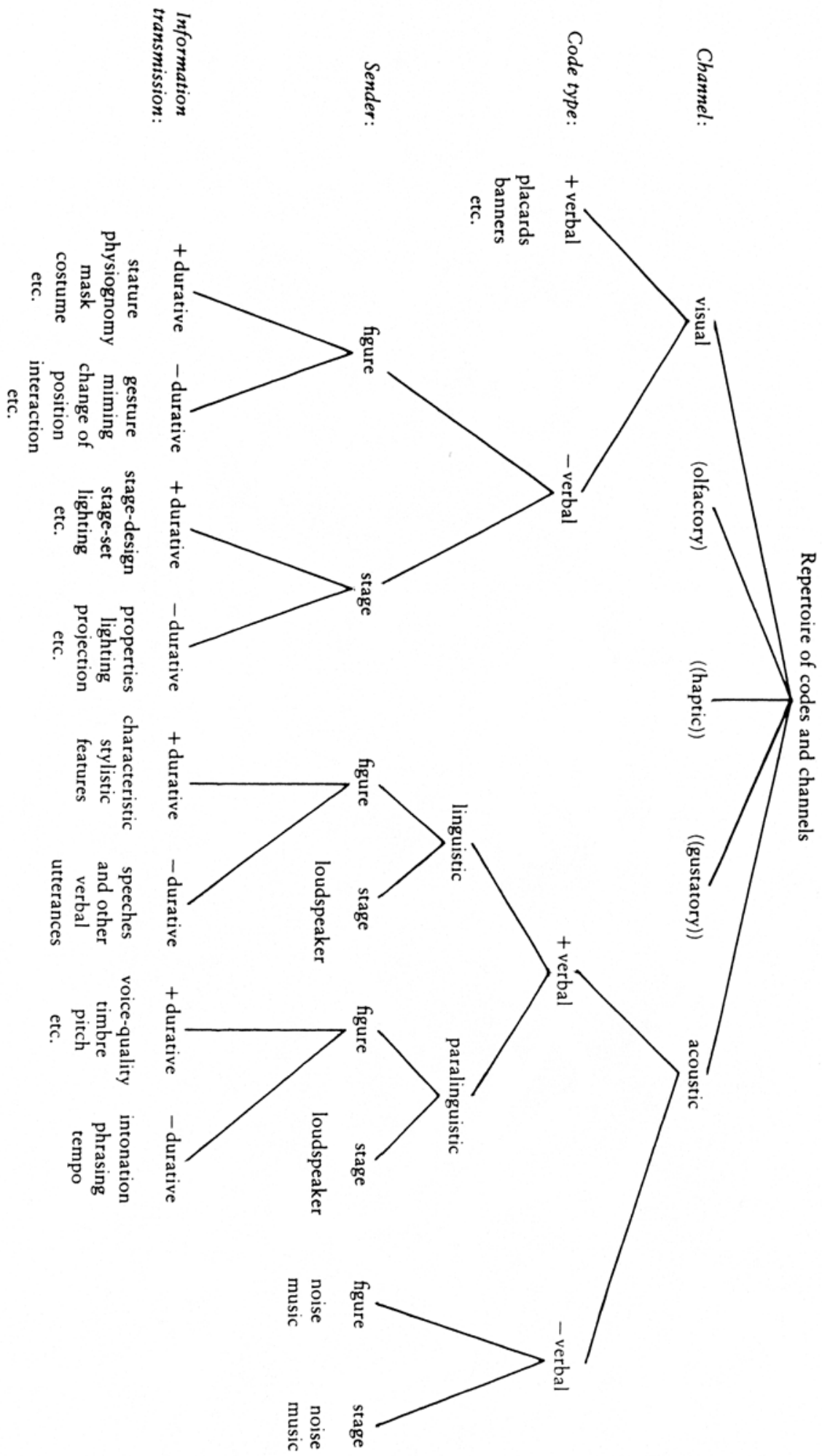
also have a role to play in the way a folk narrative works in performance. In addition to the text itself are the actual music of the text; the tone; the rhythm; the accompanying gestures; the pauses; the variation of spoken dialects; and then naturally the appearance and the identity of the performer him or herself, not to mention his or her immediate setting which will always convey something to the audience about his or her social position in society (see Pfister 1988: 8; see also Bauman 1977: 9; Kaivola Bregenhøj 1996: 117; and Foley 2002: 60 and 95). One might consider whether the storyteller has been given the key seat beside the kitchen fire, or whether they are seated immediately below the tree rather than on the periphery of the performance area. Do they have a large collection of beer glasses ranged in front of them? Moreover, as those scholars who have concentrated on individual storytellers have noted (see references given above), most storytellers (whether they are regular performers or not) also carry with them what might be referred to as "contextual baggage", just like any stage actor or Hollywood star will do. The audience will often be aware of other stories that they have previously been told, and simultaneously other "stories" that they have personally been involved in. In other words, the audience often knows a number of things about the private lives of the storyteller that will add extra meaning to the present choice of narrative, or particular choices of words or image that they use. As the audience observes the performer, their way of sitting, their expressions, even their clothes or their pipes will often send new unspoken messages that colour the spoken text. Indeed, in the process of performance, a situation may arise where the spoken words may not mean at all what they seem to mean when they are later transcribed (see Bauman 1977: 9; and Foley 2002: 84). Such is the power of the "sacred" space which has the capability of infusing words, movements and objects with extra weighted meaning, and perhaps new temporary importance. Everything heard and observed has something to say, and naturally the same thing applies to the rest of audience and their own context in the space at the particular time at which the event takes place (see for example Scheub 1990: 49; Kaivola-Bregenhøj 1996: 17; O’Súilleabháin 1973; Dégh 1969: 63-119; Niles 1999: 113-114).

Without the audience marking out the space, there is no storytelling performance. And as with a theatre performance, or a rock concert, the words, the songs, even the performers might be the same, but each event will naturally be quite individual. Once again, much of this will also depend on the immediate spatial and temporal surroundings of the performance situation. To give one example: A few years back, I was preparing to give a class on a play called Brand, written by the Norwegian playwright Henrik Ibsen. The play in question is epic in its dimensions. It deals with a man with a deep belief in God (Brand), who is prepared to lead his small township to near destruction as a means of bringing them closer to what he considers the real "heaven" and the real God. In the class, I had planned to discuss Brand's tragic idealism and how he can be seen as a tragic hero, cursed with a tragic, human flaw of character. Half an hour before I left my office for the classroom, somebody called through the door, advising me to check out a news web-site as soon as possible. The date was the 11th September, 2001 and two planes had just hit the World Trade Centre in New York. In the space of a mo- 
ment, the play I was preparing to teach changed its meaning entirely, and not only for the teacher but also for the stunned class that quietly assembled afterwards. There was now little talk of tragic heroism. In its place came hushed discussion of Ibsen's valid depiction of the real anguish and horror that any blind religious faith can bring. In short, the words of the narrative were exactly the same as they had been half an hour previously, but the received meaning had altered radically.

In short, as noted above, the social and historical context of the performance space will always have a central role to play in the actual meaning of any oral text. As has been stressed, the examination of these factors is one of the factors that has increasingly grown in importance in folk narrative studies over the last few decades as the social and socio-linguistic approach to oral texts gradually gathered interest in Europe (largely under influence from cultural anthropological departments in the United States). Excellent work in this field has been carried out by a variety of scholars such as Richard Bauman (1975; 1977; 1986; 1992; and [with Braid] 1998), Bengt Holbek (1998), Timothy Tangherlini (1994 and 1998), Annikki KaivolaBregenhøj (1996), Lauri Honko (1964 and 2002 among many other works) and of course Anna-Leena Siikala (1990 and 2005), all of whom have effectively shown how necessary it is to analyse the immediate context of legends and wonder tales alongside their texts. For example, as Ülo Valk has recently stressed (see Valk 2007, forthcoming), legends told about a particular witch in a community might also have a great deal to say about other pressures, other conflicts, other arguments troubling the immediate society of the performer and the audience.

Folk narratives have naturally always contained hidden social messages of this kind. And while some might question the precise nature of the earlier folk narrative collections now contained in the archives, it might also be argued that the recent research into the role of social and personal context also serves to underline the fact that the old published narratives - just as much as the new material gathered in present day fieldwork - will continue to function not only as superficial narratives but also, like the material we are collecting today, as doors to a greater world of social meaning and understanding, especially when coupled with further research into the living contexts that gave birth to these stories. It is not surprising that historians, after years of shying away from folklore, are now starting to return to it as a source of worldview and social attitudes in the past. Indeed, we can go further and resurrect aspects of the original performance. Like one of Shakespeare's plays, the nature and form of any folk narrative text in an archive (if understood correctly) can still say a great deal about important features of the original performance and the art of the performer, especially when allied to other contextual factors (see further Foley 2002; and Gunnell 1995). In short, all of these earlier narrative "doorways", however they were collected, have the potential to say something about background context and the wider living space that gave birth to them, spaces that should never be forgotten as scholars examine the structural symmetry of the door frames and the quaintness of the antique door handles. 
This leads the discussion to yet another element of "space" that is closely connected to the original performance setting and, simultaneously, elements of dramatic performance also found in a theatre. It should never be forgotten that in many orally told wondertales, the narrative is often closely and deliberately connected to the immediate performance space in which the story is told. Just as important, however, is the fact that the performed wondertale also has the capability of actively transforming this space, temporarily or even permanently, in the minds of the "observers". Indeed, as with an effective theatre performance or a visit to the cinema, it also has the potential of changing the "observers" themselves radically.

It is well known that wondertales have a common pattern of narrative which commonly begins in a setting exactly like that in which the storytelling session would be taking place (see Propp 1968). The account commences with the hero or heroine living in poverty on a farm, "exactly like this one". The first minutes of the story thus serve to connect the story and its living performance context tightly together: the jobs carried out are the same as those known by the audience. The same applies to the animals found on the farm, the living conditions and the geographical surroundings. Often the storyteller will bind the two worlds even closer together, connecting him or herself directly with the hero or heroine, either through unspoken (but well recognised) parallels between the lives of the two, or by the way the storyteller actively takes on the role using comments, gestures and first person narrative (see, for example, Zimmermann 2001: 494; and Röhrich 1991: 200-202). Once the connection between the story world of the past and the performance context of the present has been achieved, the door in the account (and in the minds of the audience) is opened, and the audience suddenly find themselves accompanying the hero-storyteller into a new world that is similar to that outside the real door of the farmhouse (in that it also has trees, roads, fields, mountains and streams), but now subtly different in that all of these features are now imbued with a powerful element of magic - a sense of potential and possibility. Beings, objects and powers that are usually out of sight or only hinted at in daily life, such as dwarves, witches, kings, princesses, talking cows and flying carpets have all suddenly taken effective physical shape: One step outside your farmyard gate, and you have bumped into the wonder tale equivalents of Gandalf and the road to Mordor. The story continues (like any popular modern James Bond film) with all kinds of breathtaking wonders, treasures, narrow escapes and surprisingly successful duels with evil villains (the sort of thing the average farmer would have had little time for in the middle of planting potatoes, feeding cows, cutting hay, and repairing the shaky wheel on his wheelbarrow). At the end, the audience suddenly finds itself brought back "home" again, albeit to a "home" that has radically changed in character. While the active magic may have been left outside the gate, "home" is clearly no longer what it was. The bare kitchen has now taken on the shape of a grand castle or a hall. The bare walls of the farmstead have been replaced by gold, the farm's rye bread and seed stir-about have become swan and turkey, and threadbare clothes have been replaced by satin and 
gold. The world of the old farm and even the old family themselves are often forgotten by both hero and the audience in all the excitement.

In a sense, this transformation parallels that of the hero/heroine. It has often been noted that the wondertale often takes the form of an initiation story or rite of passage. In modern terms, it tells of how the kitchen- (or bedroom-) bound son, up to his neck in SMS, MSN, hip-hop, fast food and computer games, is forced to go off on inter-rail, and returns in the form of a "real man" after fighting off muggers, terrorist kidnappers, dope-pushers and foreign police. He now has a sun-tanned princess on his arm, and is ready to go into Business Studies at university. The account ends in a castle in Silicon Valley. The acne-troubled computer "nerd" has been transformed, revealing the potential business butterfly that once lived deep within the caterpillar. In a sense, the same thing has happened to the farm setting of the story and those within it. Just as the farm boy/storyteller has "morphed" into a hero, so too has the farmhouse become a castle for the audience in the process of the telling. At a recent legend conference in Reykjavík, Ulf Palmenfelt (see Palmenfelt 2007, forthcoming) discussed the element of transformation in legends, noting the way in which legends and myths all underline the potential for sudden transformation that the everyday world had for the farmer of the past. It was a world where life could suddenly change into death, where the bare tree could burst into a cherry blossom wonder, the girl became a woman; and a cow and the potato crop could become gold. The clearly wondertale has the same quality. It can subtly alter perceptions of the space the audience sees before it during the performance.

It is possible to take this idea even further. In an article written over twenty years ago, Cheryl Oxford described an American storyteller, Ray Hicks, as being form of "shaman", noting how in his "Jack" stories he seemed to take his audiences on a shamanistic journey out of the farmhouse and into other worlds, "healing" them in the process. As Oxford notes about the role of storytellers in society:

It is consoling and comforting to know that a member of the community is able to see what is hidden and invisible to the rest and to bring back direct and reliable information about the supernatural world [---] Shamanistic storyteller Ray Hicks, who mediates between the mythic world of Jack and the immediate reality of the teller's audience, similarly bridges two worlds of experience. He thereby achieves what Victor Turner describes as 'liminality,' the state of being betwixt and between, - "that which is neither this nor that, and yet is both." His is a threshold existence, "a stage of reflection" looking fore and aft, outward and inward. Such a performer is charged with the narrative power to bring the dim and distant landscape of the imagination into closer proximity and sharper focus for the uninitiated. Through such a storied rite of passage, the teller and his listeners are able to achieve social cohesion and emotional catharsis, a reinforcement of one's own cultural heritage or a glimpse of that of the Other, an unflinching look at the terrors of life and the healing strength that comes with vicarious triumph. (Oxford 1992: 59-60). 
Even though this shamanistic element can be taken too far, the parallels between the shaman's activities, the recounted journey and the transformations of the surroundings that are worked during the course of the wonder tale are obvious, especially if one considers the art of first-class storytellers like Duncan Williamson of the travellers' community in Scotland (see, for example, Williamson 2000; and Douglas 1987 [other traveller accounts] and the films of such storytellers kept in the School of Scottish Studies at the University of Edinburgh).

J. R. R. Tolkien argued that fantasy works like The Lord of the Rings offered readers and listeners three key elements: those of Escape, Consolation and Recovery (Tolkien 1988: 52-63). What Tolkien meant by "recovery" was, in a sense, the restoration of the ability to view the world in the powerful way in which Tolkien believed early man saw it: as a world charged with mana, magic and wonder. In many ways, the wonder tale can have the same potential effect on its listeners. It adds a feeling of possibility and wonder to the mundane and normal in the everyday surroundings. Indeed this effect can be extended to the individual listener's concept of themselves. Like the modern Hollywood adventure film, the wondertale has momentarily allowed the audience to "escape", and through temporary identification with the hero or heroine, they too can feel elements of self-transformation and an infusion of personal potential.

Wondertales, however, are clearly not the only folk narrative genre to have the capability of transforming space. Most other types of narrative have similar potential, even though they remain firmly rooted in the present world. While they may not change the kitchen into a castle, legends and anecdotes have the potential of transforming the wider space surrounding the storytelling session. This is not only carried out by the obvious features of rumour and implication. As numerous scholars from the Grimm brothers onwards have stressed, the archetypal folk legend is quite different from the wondertale. ${ }^{6}$ While the telling of legends is often less intense, less structured and less intimate, they too are told in space, and they are simultaneously closely bound up with the living space inhabited by the storyteller and the audience: in this case not so much the immediate performance area itself as the area surrounding it. Once again, the effects on the listening audience will be quite different from those experienced by the reader: Listening to a legend about a place that you are familiar with is quite different from the effect of reading an unfamiliar local legend in another country. The living oral narrative can not help but add new temporal depth, character and mystery to its contextual surroundings. ${ }^{7}$ However, it does more than this: it will also offer guidelines for listeners on how to deal with these surroundings.

It has been argued that folk legends serve as a form of "road map" for the community that knows and retells them (see, for example, Gunnell 2005). Indeed, in communities like those inhabiting the Nordic and Celtic countries and the other British Isles, the storytelling sessions which formed part of the so-called evening "kvöldvökur" (wakes) or "ceilidh" sessions (see further Hermann Pálsson 1962 and Glassie 1995) seem to have served as a kind of school for those who took part. The folk legends told in such contexts were thus usually much more than simple 
entertainment. In addition to containing often unconscious messages about pressures and problems at large in the surrounding society (as noted above), they are usually also told for a didactic purpose which is more often than not quite firmly wedged between the lines. At the same time as offering their listeners information about the nature of belief - both Christian and otherwise - they also contained models of behaviour for use on different occasions, underlining what was viewed as being good, and what was evil. They thus provided their audiences with a "road map" of values and behaviour: If those listening followed the rules provided, they might live to hear another tale. If they broke the rules, they might end up in a legend themselves if not also on a list of mortality statistics.

Folk legends, however, also provide other forms of learning. Among other things, they regularly provide a great deal of information about general worldview at any given time, and especially in terms of the natural world surrounding the immediate performance context in which the legend is being told. In a sense, legends work to transform the entire local landscape in the minds of the listener. They colour it with stories, bestowing it with a historical past that might not exist on the surface, adding life to old ruins and rocks, danger to pools and lakes, and mystery and wonder to other parts. They underline routes to be taken, and routes to avoid, and draw clear borderlines between the cultured and the raw, the civilised and the wild, the natural and the supernatural, the living and the dead. Legends are the clothes worn by the landscape in the minds of the local inhabitants.

One of the problems of many of the earliest collections of legends from countries like Iceland, Scotland, Ireland, Norway and Denmark was that they (like the work of the Grimms) had a political agenda behind them. ${ }^{8}$ While serving to underline cultural connections to the so-called "survivals" published by the Grimms in Deutsche Sagen, their other key aim was to stress "local" (here in the sense of "national") differences, and "local" (again national) identity as a key element of a national struggle for independence and the "hearts and minds" of the populace (see, for example, Amundsen 2002 on the early Norwegian collections). With this latter aim in mind, the legends published in the first collections were carefully selected both for their art and for their national elements, uniqueness often having more importance than the degree of normality. The Grimms' own collection, working hard to underline pan-German cultural connections running from Holland to Switzerland and from Schleswig-Holstein to the Hungarian border is a case in point. In the context of the times, such a move was natural, even though it served to place the dead butterflies in a quite different context from that in which they originally functioned: that is to say, the real local area and the local community. Certainly, legends have something to say about national identity, but for the audiences that heard them this was a secondary function (at most). Essentially, folk legends deal with the local and the personal, something that also applies to adapted contemporary urban legends in many ways. Legends thus need to be viewed first and foremost in terms of the immediate spatial environment that produced and maintained them. 
There are various ways of doing this. At the present time (autumn 2005), work is nearing completion on two large databases of Iceland legends, one containing records of all published Icelandic legends (the so-called Sagnagrunnur: see Gunnell 2004), and while the other contains information about legends in the sound archive of the Arnamagnean Institute at the University of Iceland (see http:// www.am.hi.is/index.php). When completed, these databases will house a total of around twenty-five thousand records. One of the aims behind this work is to enable folklorists in Iceland and abroad to put the archived legends back into the own local context from which they sprang: to reconstruct the repertoires of individual storytellers and their families - in their original context; and to examine the way in which local beliefs and local legends might have functioned when originally voiced in the society that created and fed them. This move in focus from the national, the international and the intercultural to the personal, local and intracultural is of course yet another of the central developments in folk narrative study over the past few decades (see for example Kaivola-Bregenhøj 1996; 11-43; and Honko 2000: 4-15). And once again, this new understanding is closely tied up with elements of space, as the lens focuses down ever more narrowly, moving from the nation to the community, and from this to the individual life and even the internal psychology of the storyteller him or herself. It is obvious that the local worldview revealed in such research is going to differ quite radically from the national mind-set underlined by the collections. It is tightly bound up with local rivers, local mountains, local catastrophes and immediate problems with particular cows, particular outlaws and particular priests who seemed to see devils and demons wherever they looked. And each of these, too, was transformed in the telling of the tale.

Legends then, just like wondertales, are essentially bound up with space. Indeed, in many ways, it might be said that they add a fourth, temporal dimension to that space. As John Niles notes, referring to the ideas of Ricoeur, "Human time is created through narrative" (Niles 1999: 3). Quite naturally, the general concept of time for the people of the past was very different to time as viewed by modern mankind with its watches, history books and museums of archaeology. As medieval art effectively underlines, in earlier centuries, the "past" for the majority was generally seen as being very much like the present - only it was known to have taken place at some point in the past. The past itself was not the "foreign place" that it has become in our own time. Nonetheless, both legends and personal narratives served to provide a general sense of temporal depth to people's lives and their surroundings. Like memory, though, the legends that survive have always involved a great deal of selection and adaptation. Furthermore, the overall picture they provide of the past will never be impartial and objective. As noted above, legends nonetheless served as a means of enabling people to deal with their temporal as much as their natural surroundings all of which gained both age and personality through the process of the storytelling. At the same time, legends have a great deal to inform us about these concepts of time, and not least the way in which people considered and understood the present: they underline the way in which people saw time (like landscape) as having differing degrees of potential. They underline the fact that people believed there were times in their 
daily lives when the world took on an even greater dimension; in other words, liminal periods when the doors between worlds opened wide (for example at Christmas, Easter and midsummer, during wars, and during the course of personal rites of passage).

Typical examples of legends containing the temporal and spatial features noted above are legends telling of ghosts attached to a particular area. Icelandic legends concerning the ghosts of drowned foreign seamen are a case in point (see Gunnell 2005). They underline the way the seashore was viewed as liminal territory between worlds, and also how the invasion by deceased, well-dressed, foreign-speaking "outsiders" of the "home" territory of poverty-stricken Icelanders could break down mental and moral well-being, and accepted borderlines between the right and the wrong; safety and danger; and "us" and "them", especially when darkness falls. Even the accepted northern European rules concerning how to deal with "the dead without status" (see Pentikäinen 1989) disintegrate in such circumstances, the personal confusion experienced by the central figures in the legends being reflected by the recurring loss of spatial direction in the stories.

These legends, like so many others, migratory or otherwise, nonetheless clearly etch out the essential differences that people have always understood as existing between "us" and "them": they emphasise once again the ideas of differing degrees of "inside" and the "outside", simultaneously underlining the borders that make us an internal community. In a living sense, they also give their listeners a sense of spatial identity, especially in the sense of "our" area and "their" area. As noted above, this applies as much as anything else to the lines that the community saw as existing between the natural and supernatural.

Closely related to this is the central role played by place names in legends. Over and above the way in which they serve as a means of making legends sound genuine, immediate and relevant to their local listeners, place names in legends also function locally as a form of hidden language or symbol, presenting associations which are bound to remain somewhat alien to later readers who are unaware of the living, implicit repertoire of the local landscape that surrounded the performance. Like the storytellers, all place names mentioned in a local legend storytelling session come accompanied by their own baggage of associations that need no explanation for the insider. They function as cross references to a wealth of other narratives and beliefs that live within the local space and the memories of those that inhabit it.

The study of local legends in context, like the study of a local storyteller's repertoire, clearly has a great deal to say for it. Like the storyteller, the legend lives and grows within a space that forms as much a part of it as the text itself. Presented orally in its original surroundings, the legend is part of a multidimensional local language, packed with a wide range of local social, historical, geographical and linguistic associations. The same of course applies to the personal narrative, the epic and even the myth which has an even greater potential for adding dimension to the spaces that its listeners inhabit. All of these, uttered in space, passed through space, attaching themselves to objects in space alter the 
overall conceptions of the space that people inhabit. Furthermore, just as they live in time, so too do they alter concepts of time.

As stated at the start of this article, modern research has worked effectively to underline the multi-dimensional "thickness" of the oral narrative. Clearly, folk narrative of the "traditional" kind involves a great deal more than just text, and all of this additional contextual material should be noted and considered as part of any fieldwork. As underlined above, however, this does not mean that the old, essentially textual archives of folk narratives are dead and ready for burning. As scholars like Bengt Holbek and Timothy Tangherlini have effectively demonstrated in their work into Danish folk tales (see Holbek 1998 and Tangherlini 1994), the knowledge attained from fieldwork in the present can serve as a key to opening the doors contained in the material of the past. Certainly, we no longer have immediate access to the contexts surrounding the oral material of the past, and we may not agree with the methodology of past collections, but this is no reason for to confine them to the cellar or bonfire. It should never be forgotten that the results (and means) of our own modern "state of the art" fieldwork is just as likely to be coloured by fashionable, subjective elements drawn from the immediate scholarly spaces that we inhabit and the flavours of the "modern" methodologies and philosophies that we read, all of which in time are also going to find themselves considered as dated. ${ }^{9}$ Analysed by someone else from a different culture in a few years time, less influenced by topical "feminist", "queer", "postmodern", "postcolonial", "de-constructionalist" or "new historical" theories and their associated forms of scholarly vocabulary, it is quite possible that the interpretations made of our fieldwork will be quite different to those we have attained. Is our own present work therefore useless? All that scholars of any period can do is to endeavour to make sense of their material using the languages (academic and otherwise) and degrees of understanding available to them at any given time. Ideally this should be done in cooperation with others working in other disciplines such as drama, history, comparative literature, psychology or anthropology which might offer new, refreshing points of view into the various depths of the narrative. Furthermore, whatever interpretative approach is used, this will not detract from the intrinsic value of the original collected material, especially when it is viewed with understanding of its original living context.

In short, while the "thick corpus" and performance related approaches which (in Finnish scholarship in particular) draw together approaches built on the American, Hungarian, Irish and Finnish schools are clearly both valid and fruitful for present-day collection, there is no reason to despair of the archives of older material. As noted above, it is likely that the present work on compiling databases of folk narratives which is taking place in a number of countries around the world (Germany; Belgium [The Flemish folk tale database]; Estonia; the USA [a database of Tang Kristensen's legends]; and Iceland to mention a few) will help open new effective doorways of perception into the "spatial" depth of the older material. Certainly, the records contained in the databases are digital and in some ways another set of "dead butterflies" (like the decontextualised printed accounts), but they can be made more useful if the records follow the potential of the me- 
dium and do not concentrate solely on the texts. Additional fields can provide references to additional contextual material about the storytellers, their communities, their cultural connections and their surroundings, along with cross references to other databases (for example of genealogical material and historical records) and also photographs of manuscripts, environments and the people in question. They can help us understand how the narrative might have worked dynamically within its original spatial context.

Not all folk narrative, however, has this degree of depth, even when collected in the present time when all contextual material is ready and waiting for the researcher to document. Today, the methods of information dissemination are much more variable in nature than they were in the past. Material classed as folk narrative is being passed on by a variety of new means. While it still often takes the form of text, it is often presented and received in a very different way to that used with oral narrative. In print, the texts may look very similar, but in essence, they are very different creatures. Bearing in mind what has been stated above about the important roles played by performance, reception and context, there is good reason to reconsider the general approaches that have been taken with regard to folk narrative genre classification in the past. Most of these have tended to concentrate on words and textual structure rather than the nature of the performance or reception.

Questions of genre and genre definition have been very popular during the last few decades, following on from the earlier problematic questions of classification and type identification (Tangherlini 1990). Like the archive material, all of this sometimes disputed work will retain its value. Naturally, while folklore involves boundaries, it also tends to shed light on varying degrees of liminality where worlds collide. Storytellers themselves are often unsure about the classification of the material they present, and there is no question that one category of narrative will often blend into another. As Anna Leena Siikala and others have stressed, genre can also vary by area (Siikala 2005: 50 and 56). In short, genre classification, like all classification systems, is bound to be imperfect. Nonetheless, just as words are needed as a means of passing on to others information about indescribable experiences, objects and feelings, so too do we need classifications of some kind to describe folk narrative. The genres, the categories and the classifications utilised are simply the scholars' attempts at labelling the living, multi-dimensional phenomena that they are faced with in their research.

There are, however, several problems involved in classifying essentially solely on the basis of text and then age or provenance. In this article, I have underlined the essential elements of living space that need to be considered when scholars analyse spoken wondertales, personal narratives, epics, myths, and folk legends (contemporary and otherwise). From Brunvand (1981) onwards, however, scholars seem to have striven to underline the idea that "contemporary" or "urban" legends are essentially different from so-called "traditional" legends, and that all "contemporary legends" should be collected together. This is understandable to the extent that a new element of globalisation and new forms of transmission lie 
behind many of the contemporary legends. Nonetheless, the general division between the two "types" is a little unfortunate, essentially because it implies that there was a point at which "traditional" legends ceased to exist, when "contemporary" legends took over. It is noteworthy that collections of contemporary legends tend not to include contemporary legends of ghosts or fairies; similarly legends involving cars, micro-waves and hitchhikers are generally not classed alongside legends of pirates, magical mills, elves, outlaws and horses in the more traditional national collections (see however Klintberg 1987; Kvideland and Sehmsdorf 1988; and Bø et al. 1981).

Here, to a certain extent, it might be suggested that some scholars have let their desire for genre differentiation be led by superficial textual differences rather than the function, nature or reception of the texts in question. When it comes down to it, a spoken contemporary legend about a cannibalistic serial killer has little to differentiate itself from a spoken legend or wondertale about man-eating trolls. Both reflect belief systems (see Honko 1964), and, as received, both tend to contain the multi-dimensional spatial qualities that have been discussed above. In performance, both involve the semiotic features of sound, appearance, smells, living social context, and local reference. No all contemporary legends, however, are received in the same way. Within the field of contemporary legend itself, there are more drastic genre differences which often receive less attention. Material passed on by newspaper, e-mail, photocopier, web site, and SMS is in essence as different to the spoken narrative as a novel or history book is to a performed stage play or piece of improvised theatre. I would suggest that they are two very different phenomena. One is received like drama, the other like a book.

The fact that all contemporary legends tend to be classed together underlines the fact that even in 2005 we are still bound to the literary roots of our studies, concentrating on folk narratives as texts rather than multi-dimensional dramatic performances. When deciding where borderlines should be drawn, we should perhaps consider a little more the living nature of the performance and the forms of communication that are utilised in each case. ${ }^{10}$ Certainly, the written or e-mailed contemporary legend or joke and the spoken contemporary legend are both folk narratives that are passed between people, but their means of communication, and the ways in which they function are very different. While both have the potential of transforming understandings of space and the objects and people that live within it, only one of them has the "thick" multi-dimensional, personal depth of the earlier type of folk narrative documented in the old archives (see further Ong 1982, for example). In short, it is high time lines were drawn in folk narrative studies between the "performed" and the "non-performed"; between the essentially "dramatic" and the "non-dramatic". ${ }^{11}$ Different methods of dissemination demand different approaches.

Unlike the web-text or copy lore, spoken folk narrative of whatever kind it is lives, breathes and functions as a multi-dimensional phenomenon within a multidimensional space, and can never really be separated from this space which gave birth to it and can also be changed by it. Like a play in a theatre, the active oral 
narrative has the capability of temporarily creating a new, simultaneous parallel reality within the present. Like a play, it will tend to remain in this multi-dimensional form as a blend of vision, sound, words and context in the memory of the audience. Arguably, the modern approaches to analysing the multi-faceted qualities of drama and theatre performance will be found to be more useful for dealing with the "thickness" of oral narrative as it is understood nowadays. The literary approach should be confined to the merely literary phenomena. Understanding these real differences in genre may be a fruitful way forward. It may also turn out to be a means of effectively uniting the materials of the past with the means and methods of the present.

\section{Comments}

* This paper was first presented as the key note address for the $14^{\text {th }}$ Congress of the International Society of for Folk Narrative Research (ISFNR) in Tartu, 26-31 July, 2005, the theme of which was "Folk Narrative Theories and Contemporary Practices".

${ }^{1}$ See, for example Berge 1924; Delarghy 1945; Tillhagen 1946; Ó Súilleabháin 1973; Dégh 1969 and 1995; Glassie 1995; Holbek 1998; Röhrich 1991; Kaivola-Bregenhøj 1996; MacNeill (and Shaw) 1987; MacLellan (and Shaw) 2000; Tangherlini 1994; Siikaala 1990: Rósa Porsteinsdóttir 2005; and Zimmermann 2001.

${ }^{2}$ It is of course impossible to provide an exhaustive reference list here: nonetheless, alongside those works mentioned in the previous note see especially Lord 1960; Malinowski 1984 (first published 1922); Durkheim 1915; Hymes 1977; Bauman 1986 and 1992; Bauman and Sherzer 1989; Bauman and Braid 1998; Siikala 2005; and Honko 2000 (especially 3 28). See also Niles 1999; Tangherlini 1998; and Foley 2002 (and other works), and especially Kaivola-Bregenhøj 1996 (not least for an excellent review for the developments in the field over the last 150 years: 11-43).

3 The role of sight is deliberately underlined here.

${ }^{4}$ As noted above, it seems that studies in "performance context" have tended to concentrate on wider social and socio-linguistic aspects rather than the type of "performance context" used by those working in the field of drama and theatre arts, for example.

${ }^{5}$ Here once again, the word "play" is used in the widest of senses, refering to a performed monologue based around a "scheme" of some kind, and involving some impersonation: see further Kaivola-Bregenhøj 1996: 34-44 (on schemes); and Gunnell 1995: 12 (on drama).

6 Of course, there is always bound to be a grey area between the two forms, depending largely on the nature of the culture in which the stories are told: see Siikala 2005: 50 and 56.

${ }^{7}$ As Anna-Leena Siikaala has noted (2005: 56): "In a word, the oratory creates places out of spaces and attaches groups with corresponding qualities to these places".

${ }^{8}$ Indeed, this might be applied to a range of publications in the past and the present. See Jón Karl Helgason 1999 on the political functions of the various publications of the Icelandic sagas. 
9 The following comment written by Henry Glassie in 1975 has lost none of its value: "Current scholars often concern themselves fashionably with theory for theory's sake. But theory matures in dialectic with reality, and the critical faculty which enables theorists to judge, test and develop their thought comes through consideration of real people and things" (Glassie 1975: 163). In short, theories might date, but the material they deal with largely remains what it always was, ready and waiting for new approaches of interpretation.

${ }^{10}$ Of course this does not mean that the textual features should not be seen as having a central role. After all, it is the narrative aspects of a wider conversation that are being focussed on in our studies. Nonetheless, the oral text, like any dramatic presentation, always involves much more than just the text.

11 The same problems naturally occur in comparative literature studies where plays are often analysed alongside novels because they both involve words, ignoring the essential fact that they are received very differently.

\section{References}

Note that in accordance with Icelandic practice, unless they use a family name, all Icelandic authors are listed under their Christian names in this article.

Amundsen, Arne Bugge 2002. Fortelling og foredling. Andreas Faye som romantisk sagnfortolker [Telling and Processing: Andreas Faye as a Romantic Interpreter of Legends]. Amundsen, Arne Bugge \& Hodne, Bjarne \& Ohrvik, Ane (eds.). Sagnomsust: Fortelling og virkelighet [Wrapped in Legend:Storytelling and Reality]. Oslo: Novus forlag.

Bauman, Richard 1975. Differential Identity and the Social Base of Folklore. Américo Paredes \& Richard Bauman (eds.). Toward New Perspectives in Folklore. Austin: University of Texas Press, pp. 31-41.

Bauman, Richard 1977. Verbal Art as Performance. Illinois: Waveland Press.

Bauman, Richard 1986. Story, Performance and Event: Contextual Studies of Oral Narrative. Cambridge: Cambridge University Press.

Bauman, Richard 1992. Contextualisation, Tradition, and the Dialogue of Genres: Icelandic Legends of the Kraftaskáld. Alessandro Duranti \& Charles Goodwin (eds.). Rethinking Context: Language as an Interactive Phenomenon. Cambridge: Cambridge University Press, pp. 125-145.

Bauman, Richard \& Braid, Donald 1998. The Ethnography of Performance in the Study of Oral Traditions. John Miles Foley (ed.). Teaching Oral Traditions. New York: Modern Language Association, pp. 106-122.

Bauman, Richard \& Sherzer, Joel (eds.) 1989. Explorations in the Ethnography of Speaking. 2nd ed. Cambridge: Cambridge University Press.

Ben Amos, Dan 1975. Toward a Definition of Folklore in Context. Américo Paredes \& Richard Bauman (eds.). Toward New Perspectives in Folklore. Austin: University of Texas Press, pp. 3-15.

Berge, Rikard 1924. Norsk sogukunst [Norwegias Art of Storytelling]. Kristiania: Aschehoug.

Brunvand, Jan Harold 1981. The Vanishing Hitchhiker. New York: WW Norton.

Bø, Olav \& Grambo, Ronald et al. (eds.) 1981. Norske Segner [Norwegian Legends]. Oslo: Det Norske Samlaget. 
Cosentino, Donald J. 1998. African Oral Narrative Traditions. John Miles Foley (ed.). Teaching Oral Traditions. New York: Modern Language Association, pp. 174-188.

Dégh, Linda 1969. Folktales and Society: Storytelling in a Hungarian Peasant Community. Bloomington: University of Indiana Press.

Dégh, Linda 1995. Narratives in Society: A Performer-Centred Study of Narration. FFC, 255. Helsinki: Academica Scientiarum Fennica.

Delarghy, James H. 1945. The Gaelic Storyteller: With Some Notes on Gaelic FolkTales. Proceedings of the British Academy, 31, pp. 177-221. Press.

Douglas, Sheila (ed.) 1987. The King o' the Black Art. Aberdeen: Aberdeen University

Durkheim, Emilé 1915. The Elementary Forms of Religious Life [Les formes élémentaires de la vie religieuse]. Joseph Ward Swain (trans.). London: George Allen \& Unwin Ltd.

Eliade, Mircea 1958. Patterns in Comparative Religion. Rosemary Sheed (trans.). London: Sheed and Ward.

Eliade, Mircea 1964. Myth and Reality. Willard B. Trask (trans.). London: George Allen \& Unwin.

Foley, John Miles 2002. How to Read an Oral Poem. Urbana and Chicago: University of Illinois Press.

Glassie, Henry 1995. Passing the Time in Ballymenone. University of Indiana Press.

Glassie, Henry 1975. All Silver and No Brass: An Irish Christmas Mumming. Bloomington: University of Indiana Press.

Gunnell, Terry 1995. The Origins of Drama in Scandinavia. Woodbridge: D. S. Brewer.

Gunnell, Terry 2004. Íslenski sagnagrunnurinn [The Icelandic Sagnagrunnur]. Úlfar Hauksson (ed.). Rannsóknir í Félagsvísindum [Research in Social Sciences], IV. Reykjavík: Félagsvísindastofnun Háskóla Íslands, pp. 611-619

Gunnell, Terry 2005. An Invasion Of Foreign Bodies: Legends Of Washed Up Corpses in Iceland. Malan Marnersdóttir, Jens Cramer \& Arnfinnur Johansen (eds.). Eyðvinur: Heiðursrit til Eyðun Andreassen [A Festschrift to Eyðun Andreassen]. Tórshavn: Føroya Fróðskaparfelag, pp. 70-79.

Hermann Pálsson 1962. Sagnaskemmtun Íslendinga [Icelandic Storytelling]. Reykjavík: Mál og menning.

Hodne, Ørnulf 1979. Jörgen Moe og folkeeventyrene [Jörgen Moe and the Folk Tales]. Oslo: Universitetsforlaget.

Holbek, Bengt 1998. The Interpretation of Fairy Tales. FFC, 239. Helsinki: Academica Scientiarum Fennica.

Honko, Lauri 1964. Memorates and the Study of Folk Beliefs. Journal of the Folklore Institute, 1, pp. 5-19.

Honko, Lauri 2000. Thick Corpus and Organic Variation: An Introduction. Lauri Honko (ed.). Thick Corpus, Organic Variation and Textuality in Oral Tradition. Studia Fennica Folkloristica, 7. Helsinki: NNF Publications, pp. 3-28

Huizinga, Johan 1949. Homo Ludens: A Study of the Play-Element in Culture. London: Routledge \& Kegan Paul Ltd.

Hymes, Dell 1977. Foundations in Sociolinguistics: An Ethnographic Approach. London: Tavistock Publications.

Jón Karl Helgason 1999. The Rewriting of Njál's Saga:Translation, Politics and Icelandic Sagas. Clevedon: Multilingual Matters.

Kaivola-Bregenhøj, Annikki 1996. Narratives and Narrating: Variation in Juho Oksanen's Storytelling. FFC, 261. Helsinki: Academica Scientiarum Fennica.

Klintberg, Bengt af (ed.) 1987. Svenska folksägner [Swedish Folk Legends]. Stockholm: Norstedt.

Kvideland, Reimund \& Sehmsdorf, Henning K. (ed.) 1988. Scandinavian Folk Belief and Legend. Minneapolis: University of Minnesota Press. 
Lord, Albert B. 1960. The Singer of Tales. Cambridge, Mass.: Harvard University Press.

MacLellan, Lauchie 2000. Brigh an Orain: A Story in Every Song. The Songs and Tales of Lauchie MacLellan. John Shaw (ed. and trans.). Kingston \& Montreal: McGill \& Queen's University Press.

MacNeill, Joe Neil 1987. Tales until Dawn: Sgeul gu Latha. John Shaw (ed. and trans.). Kingston \& Montreal: McGill \& Queen's University Press.

Malinowski, Bronislaw 1984. Argonauts of the Western Pacific: An Account of Native Enterprise and Adventure in the Archipelagoes of Melanesian New Guinea. Prospect Heights, Ill: Waveland Press.

Niles, John 1999. Homo Narrans: The Poetics and Anthopology of Oral Literature. Philadelphia: University of Pennsylvania Press.

Ó Súilleabháin, Seán 1973. Storytelling in the Irish Tradition. Cork: Mercier Press.

Ong, Walter 1982. Orality and Literacy: The Technologizing of the Word. London and New York: Methuen.

Oxford, Cheryl 1992. Ray Hicks: The Storyteller as Shaman. Elizabeth C. Fine \& Jean Haskell Speer (eds.). Performance, Culture and Identity. Greenwood: Westport, pp. 46-82. Palmenfelt, Ulf 2007 forthcoming. Form and Other Aspects of Legends. Terry Gunnell (ed.). Legends and Landscape. Reykjavík: Háskólantgafan.

Pentikäinen, Juha 1989. The Dead without Status. Reimund Kvideland \& Henning K. Sehmsdorf (eds.). Nordic Folklore: Recent Studies. Bloomington: Indiana University Press, pp. 128-136.

Pfister, Manfred 1988. The Theory and Analysis of Drama. John Halliday (trans.). Cambridge: Cambridge University Press.

Propp, Vladímír 1968. Morphology of the Folktale. Laurence Scott (trans.). Austin: University of Texas Press.

Röhrich, Lutz 1991. Folktales and Reality. Peter Tokofsky (trans.). Bloomington: University of Indiana Press.

Rósa Porsteinsdóttir 2005. Sagan upp á hvern mann: Atta íslenskir sagnamenn og ævintýrin peirra [Each Man Has Is Own Tale: Eight Icelandic Storytellers and Their Wondertales]. Unpublished thesis at the University of Iceland.

Sándor, I. 1967. Dramaturgy of Tale-Telling. Acta Ethnographia, 16, pp. 308-310.

Schechner, Richard 2002. Performance Studies: An Introduction. London: Routledge.

Scheub, Harold (ed.) 1990. The African Storyteller: Stories from African Oral Traditions.

Dubuque, Iowa: Kendall/Hunt Publishing.

Siikala, Anna-Leena 1990. Interpreting Oral Narrative. FFC, 245. Helsinki: Academica Scientiarum Fennica.

Siikala, Anna-Leena \& Siikala, Jukka 2005. Return to Culture: Oral Tradition and Society in the Southern Cook Islands. FFC, 136. Helsinki: Academica Scientiarum Fennica. Tangherlini, Timothy 1990. "It Happened Not Too Far From Here...” A Survey of Legend Theory and Characterization. Western Folklore, 49, pp. 372-389.

Tangherlini, Timothy 1994. Interpreting Legend: Danish Storytellers and Their Repertoires. New York: Garland.

Tangherlini, Timothy 1998. Talking Trauma: Paramedics and Their Stories. Jackson, MS: University Press of Mississippi

Tillhagen, Carl-Hermann 1946. Taikon berättar: Zigenarsagor. Stockholm: Norstedt.

Tolkien, J. R. R. 1988. On Fairy-Stories. Tree and Leaf. London: Unwin, pp. 9-73.

Valk, Ülo 2007 forthcoming. Folk and Otehrs: Constructing Reality in 19th-century

Estonian Legends. Terry Gunnell (ed.). Legends and Landscape. Reykjavík:

Háskólantgafan.

Williamson, Duncan 2000. The King and the Lamp. Edinburgh: Canongate.

Zimmermann, Georges Denis 2001. The Irish Storyteller. Dublin: Four Courts Press. 
